\title{
Polychaete diversity and assemblage structure in the Oualidia Lagoon, Moroccan Atlantic coast
}

El Asri, Fatima*1,2, Zidane, Hakima ${ }^{2}$, Errhif, Ahmed ${ }^{1}$ Tamsouri, Mohamed-Naoufal $^{2}$, Maanan, Mohamed ${ }^{3}$, Malouli Idrissi, Mohamed ${ }^{2}$ and Martin, Daniel ${ }^{4}$

${ }^{1}$ Health and Environment Laboratory, Faculty of Sciences Ain Chock, University Hassan II, B.P. 5366 Maârif, 20100 Casablanca, Morocco.

2 Department of Fisheries Resources, National Institute for Fisheries Research (INRH). Route Sidi Abderrahmane Club Équestre Ould Jmel - Casablanca, Morocco.

${ }^{3}$ UMR 6554 LETG-Nantes, University of Nantes, BP 81227, 44312 Nantes, France.

${ }^{4}$ Centre for Advanced Studies of Blanes (CEAB-CSIC), Accés a la Cala St. Francesc, 14 Blanes 17300, Girona, Spain.

* Corresponding author: Fatima El Asri (e-mail: fatimaelasri25@gmail.com)

\begin{abstract}
Oualidia lagoon, a Ramsar Site on the Moroccan Atlantic coast, is heavily impacted mainly due to clam harvesting and fisheries. Understanding the functioning of the lagoon system appears as a fundamental knowledge for management and conservation. Having this in mind, 43 stations were sampled over the whole lagoon during winter 2013 and summer 2013 to analyse spatial and temporal distribution of the taxonomic composition, abundance and diversity of the polychaete assemblages. Among the thirteen species of polychaetes recorded, ten were newly reported for Oualidia lagoon. 1,051 individuals from 8 species occurred in winter and 2,784 from 13 species in summer. Hediste diversicolor and Capitella sp. were the most abundant taxa in both seasons, but only the former increased in density with the increasing distance form the lagoon opening. Temperature and salinity were higher, and Chl-a and $\mathrm{OM}$ were lower, in summer than in winter. Temperature and $\mathrm{OM}$ increased, and grain size decreased, together with an increasing distance from the lagoon opening, while salinity tended to decrease both in March and July and Chl-a tended to increase in March and to decrease in July. The structure of the polychaete assemblages was characterized by forming three main clusters, either based on sampling stations or on polychaete species. These clusters were organized according to a downstream gradient, with the stations having fine sediments and a $H$. diversicolor assemblage in the inner lagoon being replaced by stations with medium grain-sized sediment and a Capitella sp. assemblage in the mid-lagoon, which were in turn replaced by stations having sandy sediments and assemblages dominated by Glycera alba (winter) and $P$. africana (summer) in the areas closer to the lagoon inlets. The shift was, in fact, from a classical, brackish, lacunar assemblage to two different, temporal aspects of a marine assemblage (close to the inlets), with a transition assemblage in between. This corresponded with a typically paralic spatial structure whose main descriptors responded to a confinement gradient. Despite the absence of a river, the organization of the polychaete assemblages closely resembled that of an estuarine system, with the tidal regime playing a major driving role.
\end{abstract}

Keywords: Polychaete diversity, seasonal variability, assemblage structure, Oualidia lagoon, Morocco, Atlantic coast. 


\section{INTRODUCTION}

Coastal lagoons are, in general, highly productive areas acting as transitional zones between land and sea. Nevertheless, anthropogenic pressure often tends to concentrate near coastal lagoons, thus becoming a major contributor to a decrease in water quality leading to habitat degradation (Newton et al., 2003).

This is certainly the case of Oualidia, a lagoon located in the Atlantic coast of Morocco. Oualidia lagoon is a Natural Park providing a valuable refuge to a rich variety of birds, fish, plants and other wildlife, being the most important wintering area for migratory birds in Morocco. Therefore, it is one of the twenty-four Moroccan sites considered by the RAMSAR Convention as wetlands of international interest. Through the practices of boating, bathing, camping, and traditional fisheries (including fish and molluscs), the lagoon and the surrounding area supports many aspects of the local economy, culture and community relationships and, consequently, a rapid urbanization has been generated during the recent years (Maanan et al., 2014). In turn, the different land uses around the lagoon (mainly agricultural, but also industrial) and its watershed produce various kinds of pollution, all of them affecting, to some extent, the lagoon environmental conditions. Among them, heavy metals (Zourarah et al., 2007; Idardare et al., 2008; Maanan et al., 2014) and fecal pollution (Hennani et al., 2012; Hassou et al., 2014).

The macrofauna is often used in coastal monitoring studies and, particularly in softbottoms, the polychaetes are a key group (Giangrande et al., 2005). The members of this group play an important role in the functioning of the benthic ecosystems, where they may represent up to $70 \%$ of the total abundance and biomass (Gray, 1974). The polychaetes are widely used as a key taxon in bioenvironmental studies to assess natural and human-induced disturbances, as they contain pollution sensitive and tolerant species that show differential distributions along pollution gradients (e.g. Pocklington \& Wells, 1992; Gray et al., 2002; Venturini et al., 2004).

Previous studies on the lagoon functioning, including the macrofaunal component, were already carried out in some of the few Mediterranean Moroccan lagoons. Among them, the deep Nador lagoon, also known as Marchica (Guelorget et al., 1987; El Kamcha et al., 2015) or the shallower Smir lagoon (Chaouti \& Bayed, 2008). In the Atlantic coast, the macrofauna has also been studied in a few lagoons, such as Merja Zerga (Bazaïri et al., 2003), Khnifiss (Bayed et al., 1998; Dakki \& Ligny, 1988; Lefrere et al. 2015) and Oualidia. In this lagoon, however, the studies mainly focused on macrobenthic taxa, such as molluscs, shellfish, or echinoderms (El Asri et al., 2015; Chbicheb, 1996), while the polychaete diversity was analyzed nearby, but in open coastal areas, Jerf Asfar and El Jadida, located at 55 and $70 \mathrm{~km}$ far from Oualidia (Sif et al., 2012).

Therefore, our study is the first one focusing specifically on the biodiversity and structure of the polychaete fauna in Oualidia lagoon, both under spatial and temporal approaches. Accordingly, we analyse the composition and structure of the assemblages, as well as their relationships with the main environmental variables explaining both their spatial distribution and their temporal variability in the enclosed ecosystem of the Oualidia coastal lagoon. 


\section{MATERIALS AND METHODS}

\section{Study area}

Oualidia lagoon, $34^{\circ} 47^{\prime} \mathrm{N}-\neg 6^{\circ} 13^{\prime} \mathrm{W}$ and $34^{\circ} 52^{\prime} \mathrm{N}-6^{\circ} 14^{\prime} \mathrm{W}$, is located on the Atlantic coasts of Morocco (Fig. 1). The lagoon measures $7 \mathrm{~km}$ long and about $1 \mathrm{~km}$ wide. The basin occupies a north-south depression bordered by a continental cliff and a coastal consolidated dune ridge and water exchanges with the ocean occurs through a major inlet about $150 \mathrm{~m}$ wide. During spring tides there is also a secondary, shallower inlet about $50 \mathrm{~m}$ wide. The lagoon morphology is characterized by lateral channels, connected to a meandering main channel, with an average depth of $2 \mathrm{~m}$ and a maximum depth (during flood tides) that does not exceed $5 \mathrm{~m}$ (Carruesco, 1989). Flood tides cover more than $75 \%\left(2.25 \mathrm{~km}^{2}\right)$ of the lagoon surface, bringing salt water up to the most confined, inner lagoon region, as well as into a saline marsh beyond the inner dam (Fig. 1).

\section{Sampling and data analysis}

Forty-three stations (Fig. 1) were sampled in winter (March 2013) and summer (July 2013). All samples (two replicates) were collected using a Van Veen grab $(0.0625 \mathrm{~m} 2 \mathrm{in}$ surface area), except at station 43 , which was located in rocky zone and was thus sampled by scraping sixteen $25 \times 25 \mathrm{~cm}$ quadrats (until a total of $1 \mathrm{~m}^{2}$ of surface area). The samples were sieved in situ through a $1 \mathrm{~mm}$ pore size mesh. The material retained on the mesh was transferred to containers and fixed in a fixed in a $10 \%$ formalin solution.

Each station was characterized by its distance from the lagoon opening (in $\mathrm{Km}$ ), water salinity (\%) and water temperature $\left({ }^{\circ} \mathrm{C}\right)$. An additional sediment sample was collected to analyse grain size, and organic matter and chlorophyll "a" contents. Grain size was measured with a laser granulometer (Malvern, Mastersizer) at the LETG (UMR 6554, University of Nantes) and expressed as mean grain size, in $\mu \mathrm{m}$ (to be used in the correlation analyses) and as relative proportions of sand, silt and clay, in \% (to be used in the Canonical Correspondence Analysis, CCA). The percentage of organic matter (OM, \%) was obtained as the weight losses of dried samples $\left(24 \mathrm{~h}, 60^{\circ} \mathrm{C}\right)$ after ignition $\left(4 \mathrm{~h}, 450^{\circ} \mathrm{C}\right)$. The chlorophyll " $\mathrm{a}$ " content (chl-a, $\mathrm{mg} / \mathrm{m}^{2}$ ) was determined according to the Lorenzen method (Holm-Hansen et al., 1965)

The macroinvertebrates were sorted under a binocular microscope, and the polychaetes were identified to species level, whenever possible, following Gil (2011). Currently accepted species names were checked at the World Polychaete Database (Read and Fauchald, 2017). Selected specimens of the most relevant species have been deposited in the CEAB collections (reference numbers CEAB.AP.856A and CEAB.AP.856B to CEAB.AP.868).

To analyse the structure of the assemblages, the following indices were calculated: (1) species richness (S: number of species per sample); (2) species abundance (N: individuals $\left./ \mathrm{m}^{2}\right)$; (3) diversity as indicated by the Shannon index $\left(\mathrm{H}^{\prime}, \log _{2}\right.$ basis) (Shannon, 1948); and the evenness index (J') (Pielou, 1966).

The relationships between environmental variables, species density and descriptors of the assemblage structure with the distance from the lagoon opening were analysed by Pearson correlations, which were performed with the XLSTAT software (2015.5.01.23039, copyright by Addinsoft 1995-2016).

Hierarchical Ascending Classification analyses (HAC) were done both on sampling stations and polychaete species, based on the Euclidean distance and the Wards method using $\log 10(\mathrm{x}+1)$ to limit the influence of the most dominant taxa (Vakharia \& Wemmerlöv 1995, Cao et al., 1997). Communities were identified by the IndVal index (Dufrêne \& Legendre, 
1997). Wilcoxon tests were used to determine the significance $(\mathrm{P}=0.05)$ of the difference between seasons. All these analyses were carried out using the STATISTICA version 8 for Windows software.

Canonical Correspondence Analyses (CCA) were performed, using the PAST 3.0 free software package, to analyse the relationships between environmental variables and polychaete assemblages. Environmental variables and polychaete densities were $\log _{10}(\mathrm{x}+1)$ transformed prior to analysis. The significance of these relationships, as well as those of the assemblage descriptors with the environmental variables was assessed by Pearson correlation (performed with the XLSTAT software).

\section{RESULTS}

\section{Environmental parameters}

Temperature was significantly higher $(\mathrm{r}=0.000006 ; p<0.05)$ in summer $\left(16.1^{\circ} \mathrm{C}\right.$ and $\left.26.3^{\circ} \mathrm{C}\right)$ than in winter $\left(16.9^{\circ} \mathrm{C}\right.$ and $\left.19.9^{\circ} \mathrm{C}\right)$ (Fig. 2). Salinity was also significantly higher $(\mathrm{r}=0.000215, p<0.05)$ in summer $(10.5 \%$ and $39.6 \%$ ) than in winter $(10.1 \%$ ond $39.5 \%$ o (Fig. 2). Chl-a showed marked changes among the studied stations. Contrary to temperature and salinity, the Chl-a temporal pattern, as well as that of OM, showed significantly higher ( $\mathrm{r}$ $=0.000008, p<0.05$ and $\mathrm{r}=0.005282 ; p<0.05)$ values in winter $\left(1.19\right.$ and $23.41 \mathrm{mg} / \mathrm{m}^{2}$ and 1.94 to $31.97 \%$ ) than in summer (0.85 and $8.79 \mathrm{mg} / \mathrm{m}^{2}$ and 1.73 to $15.1 \%$ ) (Fig. 2).

All environmental parameters analysed except Salinity and Chl-a showed significant correlations with the distance from the lagoon opening both in March and July, positive for the temperature (Pearson coeff. $=0.758, p<0.001$ and Pearson coeff. $=0.518, p<0.001$ ) and OM (Pearson coeff. $=0.440, p=0.003$ and Pearson coeff. $=0.471, p=0.001$ ) and negative for the granulometry (Pearson coeff. $=-0.338 ; p=0.027$ and Pearson coeff. $=-0$. $448, p=0.003$ ). Although non-significant, the salinity tended to decrease with the increasing distance from the opening both in March and July, while the Chl-a tended to increase in March and to decrease in July.

\section{Polychaete abundance and structure}

3,835 polychaete specimens belonging to 13 species were collected during this study (Table 1). Among them, 1,051 individuals from 8 species occurred in winter and 2,784 from 14 species in summer.

The three most abundant species in winter were Hediste diversicolor (72.4\%), Capitella sp. $(22.9 \%)$, and Nepthys hombergii (3.2\%). The first two were also dominant in summer (64.7\% and 17\%, respectively), followed by Panousea africana (5.2\%).

In winter, only $H$. diversicolor increased significantly its density together with the increasing distance from the lagoon opening (Pearson coeff. $=0.337, p=0.027$. Conversely, in summer, there were no significant relationships with the distance from the lagoon opening, except for $P$ africana, which showed a negative correlation (Pearson coeff. $=-0.340, p<$ $0.026)$.

Polychaete densities were significantly higher $(\mathrm{r}=0.0007 ; p<0.05)$ in summer $(0$ to 392 individuals $\left./ \mathrm{m}^{2}\right)$ than in winter $\left(0\right.$ to 316 individuals $\left./ \mathrm{m}^{2}\right)$. The number of species ranged from 0 to 4 (winter) or 8 (summer). However, there were non-significant differences ( $\mathrm{r}$ $=0.190 ; p>0.05)($ Fig. 3). 
The Shannon diversity was similar in winter (0-1.09 bits) than in summer (0-1.57 bits) $(\mathrm{r}=0.091 ; p>0.05)$ and, similarly, there were non-significant differences in evenness between both seasons ( $\mathrm{r}=0.241, p>0.05)$ (Fig. 3).

The spatial distribution of the assemblage descriptors in winter revealed that only the polychaete densities were significantly, and positively, correlated with the distance for the lagoon opening (Pearson coeff. $=0.381, p=0.012$ ). The remaining descriptors (S, J, H'), although non-significant, tended to increase with the increasing distance. Conversely, in summer, all descriptors tended to decrease with the distance from the lagoon opening. However, the relationships were non-significant for $\mathrm{N}$ and $\mathrm{J}$., while they were significant in the cases of S and H' (Pearson coeff. $=-0.397 ; p=0.008$ and Pearson coeff. $=-0.437, p=$ 0.003 , respectively).

Three station clusters were obtained both during winter and summer in the HAC analyses, both for sampling stations and for polychaete species. Stations cluster 1 in winter (Fig. 4A) included 15 stations mainly from the inner region of the lagoon, characterized by having sediments mainly composed by silt and clay in different proportions, high temperatures and $\mathrm{OM}$ and a low average polychaete density $\left(43.4\right.$ individuals $\left./ \mathrm{m}^{2}\right)$. The dominant species was $H$. diversicolor, followed by Capitella sp. (Table 2). Stations cluster 2 consisted of six stations occupying mostly the inner-central region of the lagoon, having silty sandy and clayey sandy sediments, a moderately high OM, temperature and salinity, and a high average density (56.8 individuals $/ \mathrm{m}^{2}$ ). The dominant species was Capitella sp., followed by $H$. diversicolor (Table 2). Stations cluster 3 consisted of 13 stations mainly close to the lagoon opening, with predominantly sandy sediments, low temperatures and OM, and a relatively low average density (4.5 individuals $/ \mathrm{m}^{2}$. The dominant species were $N$. hombergii and Phyllodoce sp. (Table 2).

During summer (Fig. 4B), stations cluster 1 was the largest one. It included 17 stations, mainly located in the inner central region of the lagoon, characterized by having relatively high temperatures, high OM, clay and silty clay sediments and a high average density (91.8 individuals $/ \mathrm{m}^{2}$ ). The dominant species was $H$. diversicolor (Table 2). Stations cluster 2 included 10 stations, located all along the lagoon, but mostly in the central part, with moderately high \% OM and temperature, silty sand and clayey sand sediments a high average density (102.4 individuals $\left./ \mathrm{m}^{2}\right)$. As it occurred during winter, the dominant polychaetes were Capitella sp., followed by $H$. diversicolor. Stations cluster 3 included seven stations located mostly near the lagoon opening, characterized by having low temperatures and OM, very low Chl "a", a high percentage of sand, and the lowest recorded average density (28.6 individuals $/ / \mathrm{m}^{2}$ ). The dominant species were P. africana, Diopatra cf. morocensis and Nephtys kersivalensis.

The HAC analyses based on species also revealed the presence of three clusters in winter as well as in summer (Figs. 5A, 5B). Both seasons coincided in showing a species cluster 1 including $H$. diversicolor only, and a species cluster 2 including Capitella sp. only. Conversely, scpecies cluster 3 inlcuded five species in winter and eleven in summer.

\section{Relationships between the descriptors of the polychaetes assemblages and the environmental variables}

In winter, Capitella sp. and $N$. hombergii were positively correlated with OM (Pearson coeff. $=0.367, p=0.015)$ and Chl-a (Pearson coeff. $=0.385, p=0.011)$, respectively. In summer, $P$. africana showed a negative correlation with OM (Pearson coeff. $=-0.313, p<$ 0.041 ), while $H$. diversicolor and $N$. kersivalensis were positively correlated with OM 
(Pearson coeff. $=0.341, p<0.025)$ and the granulometry (Pearson coeff. $=0.480, p=$ $0.001)$.

In winter the first two CCA axes accounted for $85.93 \%$ of the observed variance. The species composition was mainly related to silt, OM and chl-a contents (Fig. 6A). In summer, the first two CCA axes accounted for $87.91 \%$ of the relationships, with the most influencing environmental variables being OM, clay and sand (Fig. 6B).

\section{DISCUSSION}

The structure of the assemblages inhabiting Oualidia largely responds to the estuarine processes and habitat mixing determined, at any given time, by the physical morphology relative to the tidal elevation inside the lagoon (El Asri et al., 2015). As it occurs all along the Moroccan Atlantic coast, tides and wind-generated waves are dominant (natural) processes governing the morphological developments (Kalloul et al., 2012). In Oualidia, however, the combined meteorological and riverine inputs are also shaping the environmental features. The salinity tended to be lower during winter as a response to the increasing precipitation, and rises in summer due to a higher evaporation rates, as well as to the lowering of the inland fresh water inputs. In addition, there was a marked upstream-downstream gradient, which the salinities being much lower upstream due to the arrival of inland freshwater (Fig. 2), as previously reported (Hassou et al., 2014; Hennani et al., 2012).

The winter increases in organic matter are linked to the arrival of a thick layer of mud following the rainwater runoff. In fact, the organic matter contents in Oualidia Lagoon were higher matter than those recorded at Moroccan lagoons, either Atlantic Sidi Moussa (3.6 and 12.3\%) (Maanan et al., 2004) or Mediterranean Nador (0, 1 and 6.3\%) (El Alami et al., 1998), but also of those in well studied European lagoons, such as the Venice lagoon $(0.43$ and $1.09 \%$ ) (Bellucci et al., 2002). In turn, the high concentrations of chlorophyll "a", originated from the leaching of agricultural lands in the watershed, are so rich in nutrients that its arrival to the lagoon results in a significant increase in chlorophyll 'a'.

Our study represents a significant contribution to the knowledge on the polychaete macrofauna living the Oualidia lagoon, as the number of species reported is almost three times than those reported by Chbicheb (1996) during four seasons from December 1992 to November 1993 (Table 1). On the other hand, 12 out of the 14 species recorded in 2013 were not listed in previous survey, while two found in 1996 appear not to be currently present (Nephtys caeca and Owenia fusiformis). These differences in the structure and diversity of the polychaete assemblages may likely be explained by the increasing levels of organic matter in the sediment, which may also be related with the changes in the hydrodynamics of the lagoon due to the construction of a pit upstream. On the other hand, despite its relatively small size, Oualidia lagoon supports rather diverse polychaete assemblages, but also of molluscs (El Asri et al., 2015), when compared with other African lagoons: Aby lagoon (9 species) (Koaudio et al., 2008); Smir lagoon (12 species) (Chaouti \& Bayed, 2005); Epe lagoon (10 species) (Uwadiae, 2009), Khnifiss lagoon (17 species) (Lefrere et al., 2015). The fact that some species could not be fully identified obey mainly to the bad preservation status of the collected materials (e.g. in the case of L.cf. koreni or G. cf. tridactila). On the other hand, there were only anterior fragments of $D$. cf. morocensis, the specimens of Phyllodoce were likely juveniles to small to distinguish the key taxonomic characters or the specimens of Harmothoe completely lack the elytra. Despite we were certain of the specimens' assignation to individual species, a requisite for biodiversity analyses, further efforts would be addressed to allow more detailed taxonomic studies that would help in confirming the identity of the doubtful species. If possible these studies would have to include samples for molecular 
studies, which would be particularly helpful in identifying species such as those belonging to the Capitella sibling species complex (Tomioka et al., 2016). Despite it intrinsic interest, these studies are far beyond the scope of the present paper.

In the Oualidia lagoon, the three most abundant species were $H$. diversicolor, Capitella sp. and $N$. hombergii. The first two were also the most dominant in summer $(64.7 \%$ and $17 \%$, respectively), followed by $P$. africana (5.2\%). This pattern of dominance differs completely with that reported in the Khnifess lagoon, where the most representative species were $D$. marocensis, Terebella lapidaria and Nicomache lumbricalis (Artemis et al., 2006). The first one was also present in Oualidia, but its abundance was very low. In the Smir lagoon, the three most dominant species were Streblospio shrubsolii (reported as $S$. dekhuyzeni), $H$. diversicolor and Alkmaria romijni (Chaouti \& Bayed, 2008). Coastal lagoons are highly variable in terms of environmental conditions, not only between their different areas, but also seasonally. This may certainly contribute to explain the reported changes in composition and dominance of the assemblages inhabiting different lagoons, but also to drastic changes in the species composition through time, particularly if there are associated changes in anthropogenic pressures (Hernandez-Guevara et al., 2008). These changes, however, are not only related to the ability of the species to respond to the environmental changes, but may also result from the existing biological interactions such as competition or predation, or may depend on intrinsic characteristics of the species, as previously discussed for similar environments (Artemis et al., 2006).

Despite the temporal environmental differences found in the lagoon, and, to some extent, the differences in composition, the structure of the assemblages was the same during the two study periods. Environmental descriptors, and particularly those related to the sediment granulometry showed a regular gradient, which was mirrored by the polychaete assemblages. In fact, the $H$. diversicolor assemblage found in the fine sediments of the inner lagoon were replaced by the Capitella sp. one in the medium grain-sized sediment of the mid. lagoon, and by the Glycera alba (winter) and P. africana (summer) ones in the sandy sediments closer to the inlets. The shift was, in fact, from a classical, brackish, lacunar assemblage to two different, temporal aspects of a marine assemblage (close to the inlets), with a transition assemblage in between.

In Oualidia, continental and marine environments are characteristically interfingered, as typically occurs in littoral lagoons (Amanieu et al., 1980), the so-called paralic environments sensu Guelorget \& Perthussot (1992). Moreover, the structure of the lagoon and the associated benthic communities defined on the basis of our data agrees with the previous findings based on a physical oceanography approach that defined the lagoon as "an estuary without a river" (Hilmi et al., 2005). This structure, as well as the functioning and the influence of the nearby agricultural fields reaching the lagoon through fresh groundwater inflows, closely resembles that described for Alfacs Bay in the Ebre's Delta (Iberian Peninsula). In this lagoon, both meio-and macrofaunal organisms are overall arranged in three main assemblages (marine, transition and brackish) from the opening to the see to the most confined part (Palacín et al., 1991, 1992). In this bay, these authors also suggested an estuarine regime in absence of a river. The main difference, from an oceanographic point of view, is that the leading force in Oualidia are tides, while in Alfacs, the main currents are mainly wind and density generated, as Mediterranean tides are virtually negligible (Camp \& Delgado, 1987). On the other hand, the highest surface and water volume, together with the largest area not submitted to confined conditions, lead to maintain much diverse assemblages in Alfacs Bay. This is particularly evident when specifically analysing the polychaetes: three assemblages in Oualidia vs. six in Alfacs, 14 species and maximal densities of less than 200 individuals $/ \mathrm{m}^{2}$ in Oualidia vs. one hundred species and up to 23,000 individuals $/ \mathrm{m}^{2}$ in Alfacs (Martin et al., 2000). 
Despite its relatively small size, Oualidia lagoon revealed to be, in many different senses (from oceanography to benthic ecology), an interesting environment. This, combined with the numerous human activities developed in the surroundings, as well as in the lagoon itself, and the declaration as a Natural Park, clearly target this lagoon as an interesting monitoring objective. Future surveys will not only show the expected changes triggered by the increasing anthropogenic influence, but may also be important in assessing the health of the lagoon ecosystem, a key issue to promote initiatives allowing to maintain or even improve the added values of the lagoon both from a naturalistic point of view (e.g. as a wintering area for migratory birds) and as a service provider (e.g. sailing, bathing, bird watching, another touristic activities).

\section{ACKNOWLEDGEMENTS}

This paper is part of a research program on coastal resources of the LERL/DRH-Casablanca (National Fisheries Research Institute), and contribution of DM to the Consolidated Research Group on Marine Benthic Ecology of the Generalitat de Catalunya (2014SGR120). Dr Joao Gil helped us with some of the most problematic identifications. We are deeply grateful to $\mathrm{Mr}$ Brahim Moutaki (INRH-Oualidia) and Mr Mohamed Amine Kaddioui (PhD-student) for their help during sampling.

\section{REFERENCES}

Amanieu M., Ferraris J. and Guélorget O. (1980) Organisation et évolution des peuplements des lagunes littorales. Application à la macrofaune benthique des étangs palavasiens. In : Barbault, R., Blandin, P., Meyer, J.A. (eds.) Recherches d'écologie théorique. Les stratégies adaptatives. Maloin Editorial. pp. 251-277.

Artemis N., Petrou K., Kormas K.A. and Reizopoulou S. (2006) Inter-annual variability of soft bottom macrofaunal communities in two Ionian Sea lagoons. Hydrobiologia. 555, 89-98.

Bayed A., El Agbani M.A. Fekhaoui M. and Schouten J. (1988) Benthos of soft substrates in the intertidal zone of the Khnifiss lagoon. In: Dakki de Ligny W. The Khnifiss Lagoon and its surrounding environment (Province of La'youne, Morocco). Travaux Institut Scientifique Rabat, hors-série, 71-80.

Bazaïri, H., Bayed, A., Glémarec, M. and Hily, C. (2003) Spatial organisation of macrozoobenthic communities in response to environmental factors in a coastal lagoon of the NW African coast (Merja Zerga, Morocco). Oceanologica Acta. 26, 457-471.

Bellucci L.G., Frignani M., Paolucci D. and Ravanelli M. (2002) Distribution of heavy metals in sediments of the Venice Lagoon: the role of the industrial area. Science of the Total Environment. 295, 35-49.

Bennouna A., Assobhei O., Berland, B. and El Attar, J. (2000) Étude des populations phytoplanctoniques de la lagune de Oualidia (Maroc); dinoflagellés potentiellement nuisibles. Marine Life. 10, 3-18.

Bouchet, P., Gofas, S. (2016) World register of marine species. Accessed through http://www.marinespecies.org.

Camp J. and Delgado M. (1987) Hidrografía de las bahías del Delta del Ebro. Revista Cubana de Investigaciones Pesqueras. 51, 351-369.

Cao Y., Bark A.W. and Williams W.P. (1997) A comparison of clustering methods for river benthic community analysis. Hydrobiologia. 347, 24-40.

Chaouti A. and Bayed A. (2005) Diversité taxonomique et structure de la macrofaune benthique des substrats meubles de la lagune de Smir. Travaux de l'Institut Scientifique.4, 33-42.

Chbicheb A. (1996) Organisation biogéologique d'un bassin paralique: la lagune d'Oualidia (côte atlantique marocaine). $\mathrm{PhD}$ thesis. University of Nantes, Nantes, France. 
Carruesco C. (1989) Genese et evolution de trios lagunes du littoral atlantique depuis l'holocène : Oualidia - Moulay Bousselham (Maroc) et Arcachon (France), Tome I, 24- 100.

Chaouti, A. and Bayed, A. (2008) Spatial patterns of soft-bottom macro-invertebrates and relationships with environmental conditions in a north African coastal lagoon (Smir lagoon, Morocco). Vie et Milieu 58, 25-35.

Dakki M. and de Ligny W. (1988) The Khnifiss lagoon and its surrounding environment (Province of La'youne, Morocco). Travaux Institut Scientifique de Rabat, Hors-série. 1-172.

Delle Chiaje, S. (1841 \& 1844) [POLYCHAETA context] Descrizione e Notomia degli Animali Invertebrati della Sicilia Citeriore osservati vivi negli anni 1822-1830. [Tome 1, 98 pp.; Tome 2, 146 pp; Tome 3, 142 pp [Molluschi Acefali, Bracciopedi, Cirropedi, Crostacei, Anellosi]; Tome 4, 142 pp.; Tome 5, 165 pp. [1841, incl. Annelosi Afroditici]; Tome 6-7, pl. 1-173 [1841], pl. 174-181 [1844]; Tome 8 (Appendici, osservazioni critiche, indice generale), 48 pp. [1844] Napoli, Stabilimento Tipografico di C. Batelli e Co.

Dufrêne M. and Legendre P. (1997) Species assemblages and indicator species: the need for a flexible asymmetrical approach. The Ecological Society of America. 67, 345-366.

El Alami M., Mahjoubi R., Damnati B., Kamel S., Icole M. and Taieb M. (1998) Sédimentologie et géochimie organique des sédiments superficiels de la lagune de Nador (Maroc nord-oriental). Journal of African Earth Sciences. 26, 249-259.

El Asri F., Zidane H., Maanan M., Tamsouri M and Errhif A. (2015) Taxonomic diversity and structure of the molluscan fauna in Oualidia lagoon (Moroccan Atlantic coast). Environmental Monitoring and Assessment. 187, 1-10.

El Kamcha R, Bououarour O, Boutahar L, El Fatouani Z, El Adnani A, Zourarah B, Sghaier YR, Benhoussa A, Bazairi H. (2015) Assessment of the environmental health status of the Marchica lagoon (Morocco, Mediterranean) using Cymodocea nodosa meadows and its associated macrofauna: preliminary results. PeerJ PrePrints 3:e1325

Fabricius O. (1780) Fauna Groenlandica, systematice sistens, Animalia Groenlandiae occidentalis hactenus indagata, quoad nomen specificum, triviale, vernaculumque synonyma auctorum plurium, descriptionem, locum, victum, generationem, mores, usum, capturamque singuli prout detegendi occasio fuit, maximaque parte secundum proprias observationes, Hafniae [Copenhagen] et Lipsiae.

Faraco L. F. D. and Lana P. C. (2003) Response of polychaetes to oil spills in natural and defaunated subtropical mangrove sediments from Paranaguá Bay (SE Brazil). Hydrobiologia. 496, 321-328.

Giangrande, A., Licciano, M. and Musco, L. (2005) Polychaetes as environmental indicators revisited. Marine Pollution Bulletin 50, 1153-1162.

Gil J. (2011) The European fauna of Annelida Polychaeta. Doctoral Thesis, Universidade de Lisboa, Lisboa. http://hdl.handle.net/10451/4600

Gray J. S. (1974) Animal-sediment relationships. Oceanography and Marine Biology. An Annual Review.12, 223-261.

Gray J. S. (2002) Species richness of marine soft sediments. Marine Ecology Progress Series. 244, 285-297.

Guelorget O. and Perthuisot J.P. (1992) Paralic Ecosystems. Vie et Milieu. 42, 215-251.

Guelorget, O., Perthuisot, J., Frisoni, G. and Monti, D. (1987) Le rôle du confinement dans l'organisation biogéologique de la lagune de Nador (Maroc). Oceanologica acta 10, 435-444.

Hassou N., Maanan M., Hennani M., Zourarah B. and Assobhei O. (2014) Spatial and temporal variation of faecal pollution indicators (Escherichia coli and faecal streptococci) and physicochemical parameters at the Oualidia lagoon and its watershed (Morocco). International Journal of Current Microbiology and Applied Sciences. 3, 675-694.

Hennani M., Maanan M., Robin M., Chedad K. and Assobhei O. (2012) Temporal and spatial distribution of faecal bacteria in a Moroccan lagoon. Polish Journal of Environmental Studies. 21, 627-634.

Hernández-Guevara N.A., Pech D. and Ardisson, P. (2008) Temporal trends in benthic macrofauna composition in response to seasonal variation in a tropical coastal lagoon, Celestun, Gulf of Mexico. Marine and Freshwater Research 59, 772-779.

Hilmi K., Koutitonsky V., Orbi A., Lakhdar J. and Chagdali M. (2005) Oualidia lagoon, Morocco: an estuary without a river. African Journal of Aquatic Science. 30, 1-10. 
Holm-Hansen O., Lorenzen C.J., Holmes R.W. and Strickland J.D.H. (1965) Fluorometric Determination of Chlorophyll. Journal of Marine Science. 30, 3-15.

Horst R. (1919) Twee sedentaire Polychaeten uit he brakke water var Nederland. Zoologische Mededeelingen (Leiden), 5, 100-102.

Idardare Z., Chiffoleau J.F., Moukrim A., Ait Alla A., Auger D., Lefrere L. and Rozuel E. (2008) Metal concentrations in sediment and Nereis diversicolor in two Moroccan lagoons: Khnifiss and Oualidia. Chemistry and Ecology. 24, 329-340.

Kalloul S., Hamid W., Maanan M., Robin M. and Sayouty E.H. (2012) Source contributions to heavy metal fluxes into the Loukous Estuary (Moroccan Atlantic Coast). BioOne. 28, 174-183.

Koaudio K.N., Diomandé D., Ouattara A., Koné Y.J.M. and Gourène G. (2008) Taxonomic diversity and structure of benthic macroinvertebrates in Aby Lagoon (Ivory Coast, West Africa). Pakistan Journal of Biological Science. 11, 2224-2230.

Lamarck J.B. (1818) Histoire naturelle des Animaux sans Vertèbres, présentant les caractères généraux et particuliers de ces animaux, leur distribution, leurs classes, leurs familles, leurs genres, et la citation des principales espèces qui s'y rapportent; précédée d'une introduction offrant la détermination des caractères essentiels de l'animal, sa distinction du végétal et des autres corps naturels, enfin, l'exposition des principes fondamentaux de la zoologie. Vol. 5, Paris: Déterville \& Verdière.

Lefrere L., Ouassas M., Guillois B., Gillet P. and Moukrim A. (2015) Macrobenthic community structure of soft-bottom sediments in the Khnifiss lagoon, South of Morocco. Journal of Material and Envrionmental Science. 6, 2226-2236.

Maanan M., Zourarah B., Carruesco C., Aajjane A. and Naud J. (2004) The distribution of heavy metals in the Sidi Moussa lagoon sediments (Atlantic Moroccan Coast). Journal of African Earth Sciences. 39, 473-483.

Maanan M., Ruiz-Fernández A.C., Maanan M., Fattal P., Zourarah B. and Sahabi M. (2014) A long-term record of land use change impacts on sediments in Oualidia lagoon, Morocco. International Journal of Sediment Research. 29, 1-10.

McIntosh W.C. (1908) A monograph of the British annelids, London: Ray Society.

Malmgren A.J. (1866) Nordiska Hafs-Annulater. Öfversigt af Königlich Vetenskapsakademiens förhandlingar, Stockholm, 22(1), 51-110.

Martin D., Pinedo S. and Sardá R. (2000) Distribution patterns and trophic structure of soft-bottom Polychaete assemblages in a North-Western Mediterranean shallow-water Bay. Ophelia. 53, 1-17.

Müller O.F. (1776) Zoologicae Danicae Prodromus, seu Animalium Daniae et Norvegiae indigenarum characteres, nomina et synonyma imprimis popularium, Havniae [Copenhagen]: Hallageriis.

Natij L., Damsiri Z., Khalil K., Loudiki M., Ettahiri O. and Elkalay K. (2014) Phytoplankton abundance and diversity in the coastal waters of Oualidia lagoon, south Moroccan Atlantic in relation to environmental variables. International Journal of Advanced Research. 2, 1022-1032.

Newton T.J., Allran J.W., O'Donnell J.A., Bartsch M.R. and Richardson W.B. (2003) Effects of ammonia on juvenile unionids (Lampsilis cardium) in laboratory sediment toxicity tests. Environmental toxicology and chemistry. 22, 2554-2560.

Palacín C., Martin D. and Gili J.M. (1991) Features of spatial distribution of benthic infauna in a Mediterranean shallow-water bay. Marine Biology. 110, 315-321.

Palacín C., Gili J.M. and Martin D. (1992) Evidence for coincidence of meiofauna spatial heterogeneity with eutrophication processes in a shallow-water Mediterranean bay. Estuarine, Coastal and Shelf Science. 35, 1-16.

Paxton H., Fadlaoui S. and Lechapt J.-P. (1995) Diopatra marocensis, a new brooding species of Onuphidae (Annelida: Polychaeta). Journal of the Marine Biological Association of the United Kingdom, 75, 949-955.

Pielou E. C. (1966) Shannon's formula as a measure of specific diversity: its use and measure. American Naturalist. 100, 463-465.

Pocklington P., Wells P.G. (1992) Polychaetes. Key taxa for marine environmental quality monitoring. Marine Pollution Bulletin.24, 593-598.

Read G. and Fauchald K. (Ed.) (2017) World Polychaeta database. Accessed at http://www.marinespecies.org/polychaeta on 2017-01-16. 
Renier S.A. (1804) Prospetto della Classe dei Vermi, nominati el ordinati secondo il Sistemo de Bosc, Padua.

Rullier F. and Amoureux L. (1970) Nouvelle contribution a l'étude de la faune des Annélides Polychètes du Maroc. Bulletin de la Société des Sciences Naturelles et Physiques du Maroc, 49(1/2), 109-142.

Schmarda L.K. (1861) Neue wirbellose Thiere beobachtet und gesammelt auf einer Reise un die Erdr 1853 bis 1857. Erster Band (zweite halfte) Turbellarian, Rotatorien un Anneliden, Leipzig: Wilhelm Engelmann.

Shannon C.E. (1948) A mathematical theory of communication. Bell System Technical Journal. 27,379-423.

Sif J., Rouhi A., Gillet P. and Moncef M. (2012) Diversité et écologie des Annélides Polychètes du littoral atlantique de la région d'El Jadida (Maroc). Bulletin de l'Institut Scientifique, Rabat, section Sciences de la Vie. 34, 95-106.

Tomioka S., Kondoh T., Sato-Okoshi W., Ito K., Kakui K. and Kajihara H. (2016) Cosmopolitan or Cryptic Species? A Case Study of Capitella teleta (Annelida: Capitellidae). Zoological Science, 33(5), 545-554.

Uwadiae R.E. (2009) Response of benthic macroinvertebrate community to salinity gradient in a Sandwiched coastal lagoon. Report and Opinion. 1, 45-55.

Vakharia A.J. and Wemmerlöv U. (1995) A comparative investigation of hierarchical clustering techniques and dissimilarity measures applied to the cell formation problem. journal of operational management. 13,117-138.

Venturini N., Tommasi L.R., Bícego M. C. and Martins C. C. (2004) Characterization of the benthic environment of a coastal area adjacent to an oil refinery, Todos os Santos Bay (NEBrazil). Brazilian Journal of Oceanography. 52, 123-134.

Zourarah B., Maanan M., Carruesco C., Aajjane A., Mehdi K. and Conceição Freitas M. (2007) Fifty-year sedimentary record of heavy metal pollution in the lagoon of Oualidia (Moroccan Atlantic coast). Estuarine, Coastal and Shelf Science. 72, 359-369. 
Table 1: Comparative analysis of the polychaetes identified in our study with those identified by Chbicheb (1996) in Oualidia lagoon

\begin{tabular}{|c|c|c|c|c|}
\hline Family & Species & This & study & 1996 \\
\hline & & Winter & Summer & \\
\hline Nereididae & Hediste diversicolor (O.F. Müller, 1776) & * & * & * \\
\hline Capitellidae & Capitella sp. & * & * & * \\
\hline Ampharetidae & Alkmaria romijni Horst, 1919 & $*$ & $*$ & \\
\hline Sabellidae & Panousea africana Rullier \& Amoureux, 1970 & * & * & \\
\hline \multirow[t]{3}{*}{ Nepthyidae } & Nephtys hombergii Savigny in Lamarck, 1818 & * & * & * \\
\hline & Nephtys kersivalensis McIntosh, 1908 & & * & \\
\hline & Nephtys caeca (Fabricius, 1780) & & & * \\
\hline Phyllodocidae & Phyllodoce sp. & * & * & \\
\hline Onuphidae & $\begin{array}{l}\text { Diopatra cf. marocensis Paxton, Fadlaoui \& Lechapt, } \\
1995\end{array}$ & * & * & \\
\hline \multirow[t]{2}{*}{ Glyceridae } & Glycera alba (O.F. Müller, 1776) & * & * & \\
\hline & Glycera cf. tridactyla Schmarda, 1861 & & * & \\
\hline Lumbrineridae & Lumbrineris coccinea (Renier, 1804) & & * & \\
\hline Polynoidae & Harmothoe sp. & & * & \\
\hline \multirow[t]{2}{*}{ Pectinariidae } & Lagis cf. koreni Malmgren, 1866 & & * & \\
\hline & Owenia fusiformis Delle Chiaje, 1844 & & & * \\
\hline
\end{tabular}


Table 2 List of the main species of each polychaete assemblages according to the IndVal index. Assemblages are named according to the species showing the highest IndVal (in bold).

\begin{tabular}{|c|c|c|c|}
\hline Season & Cluster & Species & IndVal \\
\hline \multirow{9}{*}{ Winter } & \multirow[t]{3}{*}{1} & Hediste diversicolor & 238.4 \\
\hline & & Panousea africana & 19.1 \\
\hline & & Diopatra cf. marocensis & 19.1 \\
\hline & \multirow[t]{3}{*}{2} & Capitella sp. & 651.2 \\
\hline & & Hediste diversicolor & 114.0 \\
\hline & & Alkmaria romijni & 29.9 \\
\hline & \multirow[t]{3}{*}{3} & Glycera alba & 94.5 \\
\hline & & Phyllodoce sp. & 63.0 \\
\hline & & Nephtys hombergii & 50.0 \\
\hline \multirow{9}{*}{ Summer } & \multirow[t]{3}{*}{1} & Hediste diversicolor & 169.8 \\
\hline & & Alkmaria romijni & 5.9 \\
\hline & & Harmothoe sp. & 3.9 \\
\hline & \multirow[t]{3}{*}{2} & Capitella sp. & 340,0 \\
\hline & & Glycera alba & 120.9 \\
\hline & & Lumbrineris coccinea & 87.4 \\
\hline & \multirow{3}{*}{3} & Panousea africana & 179.6 \\
\hline & & Diopatra cf. marocensis & 138.8 \\
\hline & & Nephtys kersivalensis & 55.5 \\
\hline
\end{tabular}




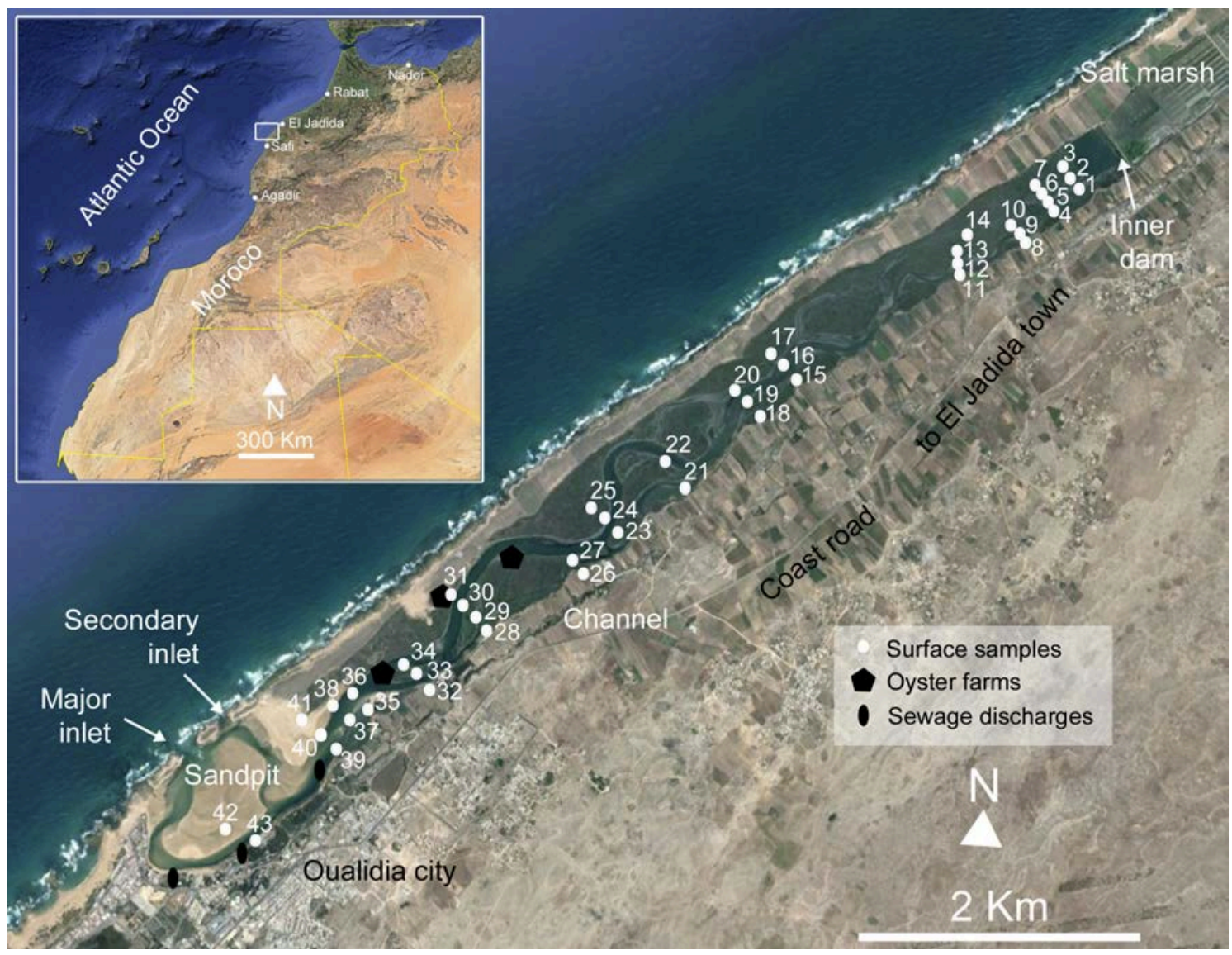

Fig.1. Map of the study area, showing the location of sampling sites in Oualidia lagoon. 

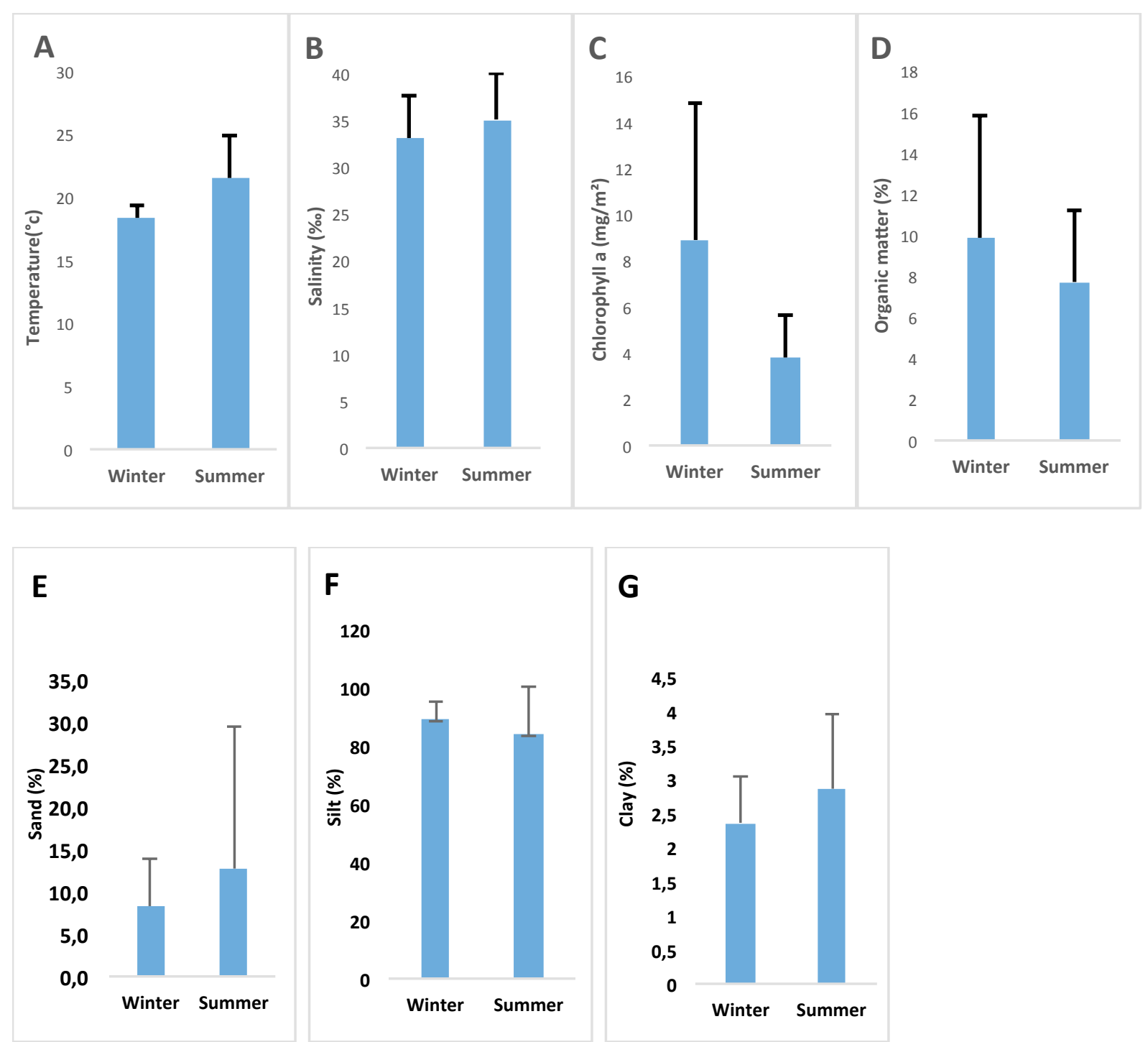

Fig. 2. Winter and summer differences in water temperature, water salinity, organic matter, chlorophyll "a" content and granulometry (Silt, Clay and Sand contents) in the sediment of Oualidia lagoon. Mean $\pm \mathrm{sd}$. 

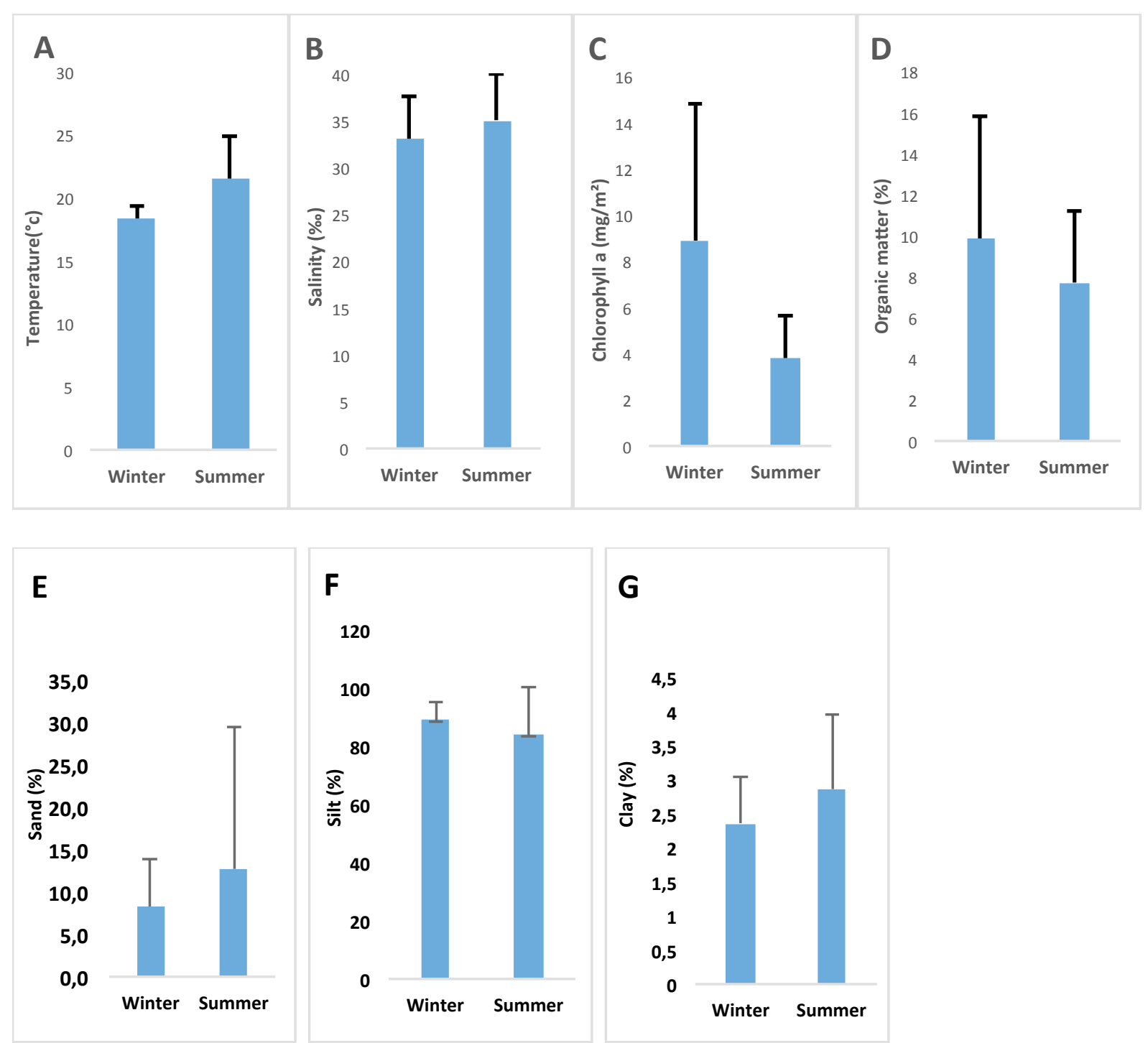

Fig. 3. Winter and summer differences in the main descriptors of the structure of the polychaete assemblages. A. Density (ind. $\mathrm{m}^{-2}$ ). B. Species richness. C. Shannon diversity. D. Evenness. 
Tree diagrams for 34 cases - Wards method - Euclidean distances
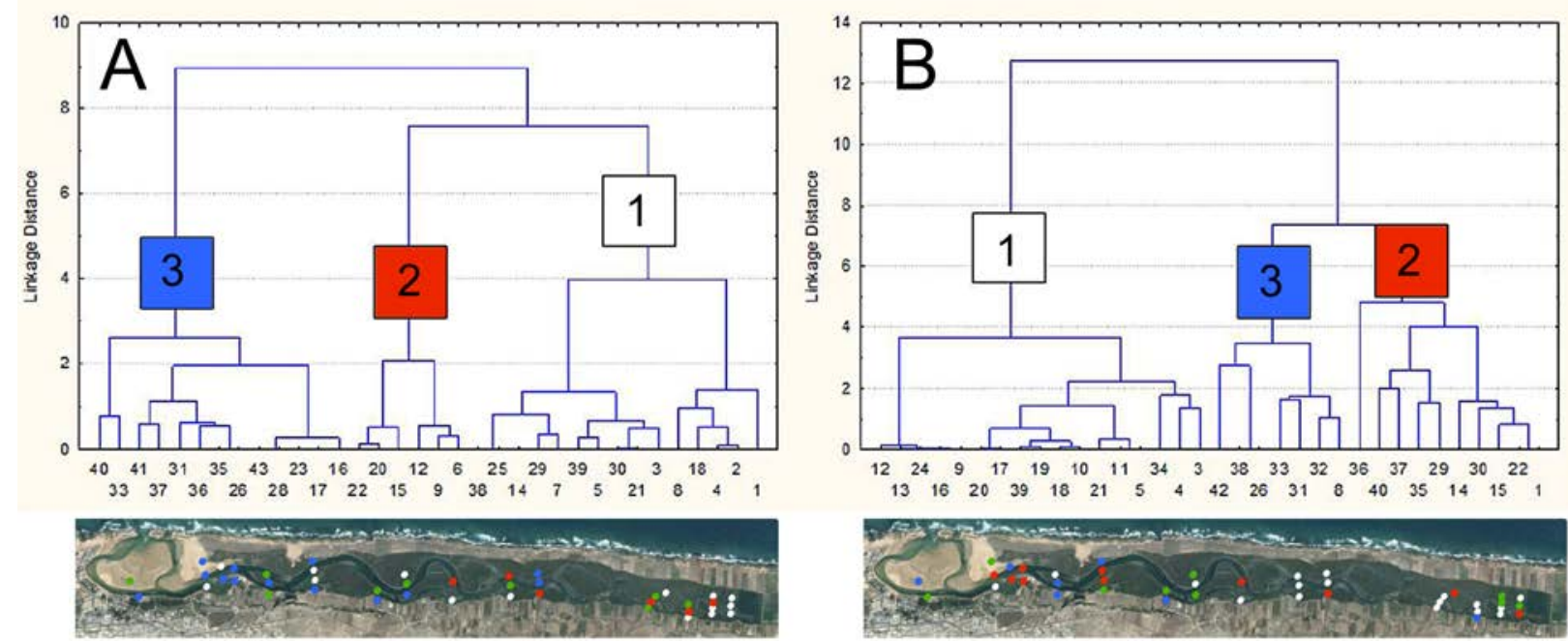

- Stations ommited from cluster analyses (polychaetes absent)

Fig. 4. Winter (A) and summer (B) dendrograms showing the three station clusters obtained in the Hierarchical Ascending Classification analysis, and the location of the respective stations in the lagoon. 

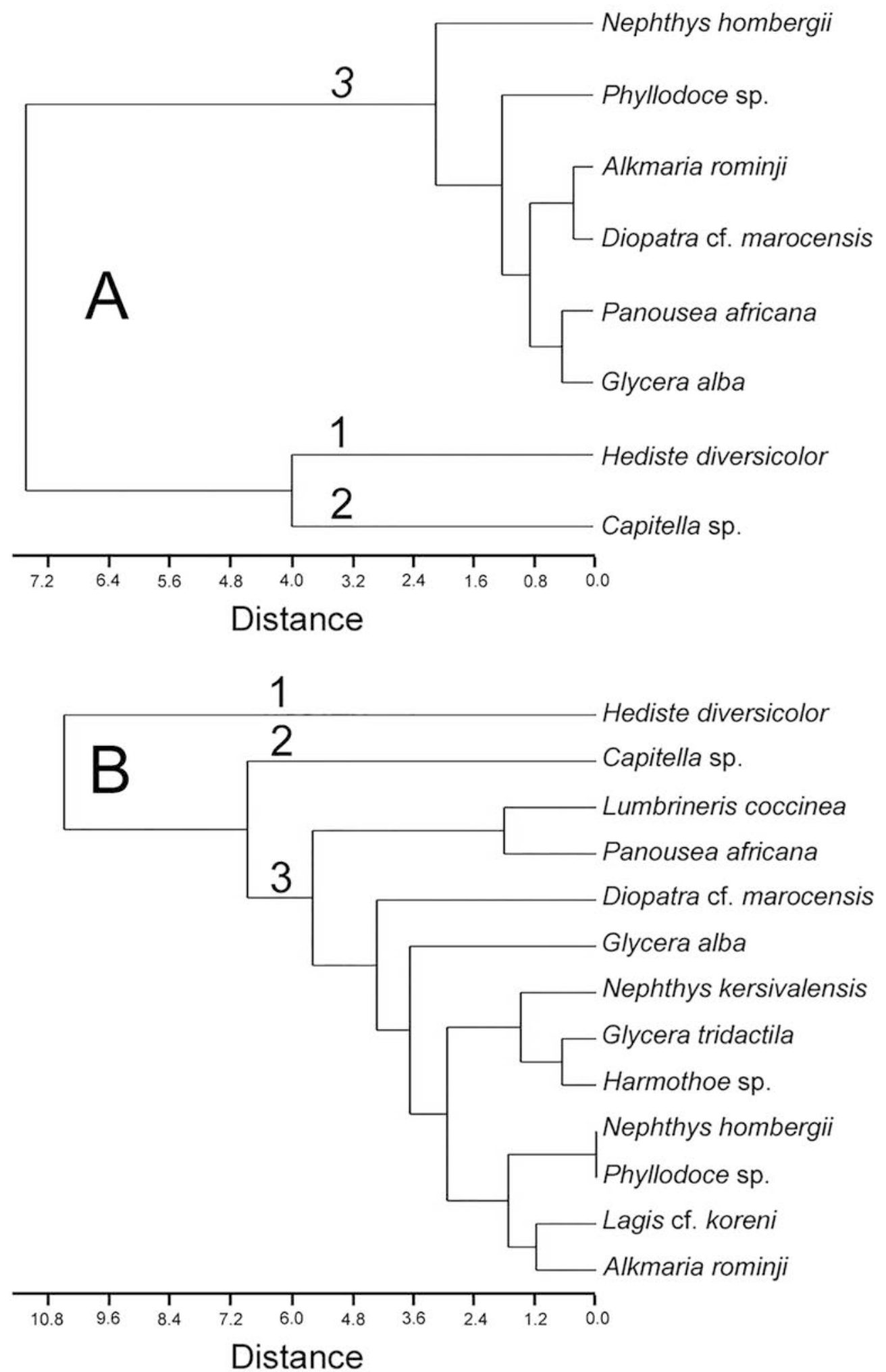

Fig. 5. Winter (A) and summer (B) dendrograms showing the three species clusters obtained in the Hierarchical Ascending Classification analysis. 

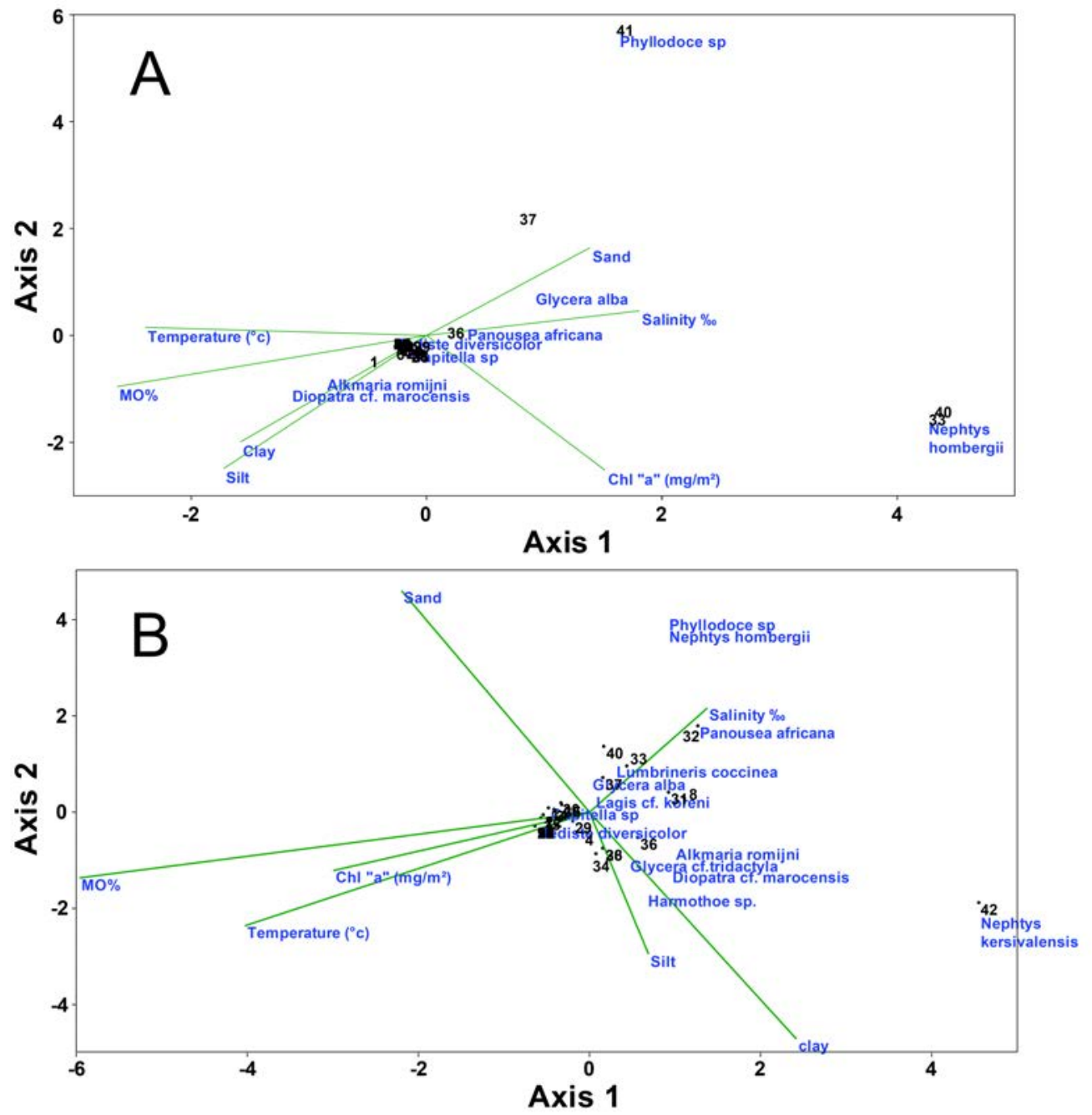

Fig. 6. Canonical Correspondence Analysis plots. A. Winter. B. Summer. 